\title{
MAIN POLITICAL AND ECONOMIC EVENTS OF FEBRUARY 2016
}

S.Zhavoronkov

In February 2016, the RF Government actively discussed its anti-crisis plan and reached a consensus to the effect that the automotive and housing construction industries, as well as non-raw material exports and agriculture, should be subsidized from the budget. At the same time, the Government failed to strike a balance between its good intentions and budget revenue. To further complicate matters, the anti-crisis plan omitted the issue of the debt of Vnesheconombank, whose head Vladimir Dmitriev resigned in mid-February. It should also be noted that in January and February 2016, oil prices were twice lower than those envisaged in the budget. As a result, the Government came to the decision that in April 2016 the budget should be considerably revised. As a matter of fact, the Government did not discuss any specific cuts in budget expenditure, while its privatization plans were encumbered by a number of conditions that could hardly attract many bidders. In a separate development, in Syria, where Russia had become engaged in an aerial campaign against the Islamic State terrorist organization, the government of Bashar al-Assad and some of the armed opposition groups announced that they had reached a truce deal. However, neither a political nor a military solution to the Syrian crisis appears to be in the offing.

In Russia, the main developments of February 2016 took place in the economic field. On the whole, they were related to the discussion of the RF Government's anti-crisis plan and the quest for the means of its realization. It should be reminded that the Government interpreted that plan as a selection of very wide range of various measures - from those that had already been stipulated in the Federal Law on the Federal Budget for 2016 to those whose funding sources were yet to be found, and then to those that would not require funding (although the latter characteristic is admittedly a rather dubious notion - for example, the issue of a state guarantee would not, at best, require allocation of hard cash, but at worst, it would). Minister of Finance Anton Siluanov announced that out of the Rb 250 bn constituting the anti-crisis fund, the Government would be able to spend a mere Rb 120bn, while the rest of the money (up to $\mathrm{Rb} 342 \mathrm{bn}$ ) could be allocated only from the Presidential Reserve Fund. It should be noticed that initially the aforesaid Reserve Fund had been tacitly intended to be spent on the eve of the 2016 parliamentary election on an additional indexation of pensions, and not on public investment. Having been initially arranged to take place on 1 February 2016, the adoption of the plan was repeatedly postponed. Finally, it was adopted (but not published) on 29 February. The most important - and costly - initiatives proposed under that plan are as follows: public support to the automotive industry by way of subsidizing the scrapping of an old vehicle when a new one is purchased; public support to residential construction by way of subsidizing mortgage provision; public support to the machinebuilding industry by way of subsidizing the purchasing of new rolling stock by JSC Russian Railways; subsidization of some non-raw material exports and 
subsidization of agriculture as a whole; and allocation of budget credits to the regions faced with the problem of unpaid wages earned by budget-funded workers (which reemerged in 2015 after an interval of many years). The ministers responsible for social securities issues insist that pensions should continue to be indexed. It should be said that even leaving aside the proximity of the parliamentary election, their position on that issue is not without good reason: back in 2008 and 2009, it was heavy public spending on the indexation of both pensions and the wages of federal budget-funded workers that constituted one of the major components of the Government's anticrisis measures. However, this time the Government is planning to finance pension and wage indexation by way of increasing the already substantial mandatory insurance payments - at least with regard to large salaries. It is noteworthy that the proposed measures designed to render public support to small businesses, including an increase in the turnover threshold for the simplified tax system to $\mathrm{Rb} 120 \mathrm{~m}$, will inevitably result in a loss of budget revenue. Furthermore, they will make no sense for an overwhelming majority of entrepreneurs, who have never had such a high turnover. Under these circumstances, Russia's authorities, for example, have so far postponed the long-promised abolition of the transport tax at least for heavy vehicles (that are also subject to a number of other charges). Although the proposal to abolish this tax was put forth as early as December 2015, in the course of President Putin's press conference, it appears that the Government has returned this issue to square one and is going to resume its 'discussion'. So far, so good, but from 1 April 2016, excise taxes on motor gasoline, diesel fuel, directly distilled gasoline and middle distillates will be significantly increased in accordance with a law passed in February 2016.

It should be noted that in January and February 2016, average monthly crude oil prices remained below the level of $\$ 30$ per barrel, which represented a 1.5 times drop on their level a year ago, while the current budget is based on an average oil price target of $\$ 50$ per barrel - that is, the average annual price of oil of last year. Unlike Russia's previous budgets, her 2016 budget does not have any safety margin in the form of a negatively biased forecast. According to Minister of Finance Anton Siluanov's forecast, if the price of oil hovers at the level of $\$ 25$ per barrel, Russia's budget will lose some $\mathrm{Rb} 3$ trillion in revenues - in addition to the Rb 2 trillion, the RF Government is planning to spend from the Reserve Fund whatever happens. As a matter of fact, unless oil prices go up sharply, the budget will certainly prove unrealizable even in the medium-term perspective (although it will be still possible to temporarily bail it out after the exhaustion of the Reserve Fund in 2016 - at the expense of the National Wealth Fund). After these two funds are emptied, the only alternative to cutting expenditure will be an increase in taxation and printing more money in order to cover the budget deficit. The idea of resorting to the printing press has become increasingly popular in the top echelons of the ruling United Russia party, in the industrialist community, etc. It is highly unlikely though, that the application of this method would result in the most glorious consequences promised today by its adherents. This experiment would most likely end up as a similar one did in Belarus in 2010, when the pre-election money-printing designed to cover the budget deficit resulted not in 'an increase of the degree of the economy's monetization' and other successes, but in a considerable devaluation of the national currency and in the inflation rate climbing to $118 \%$. 
Bearing in mind the current policy of the President and the Government, it is quite clear that public spending is not going to be radically cut: nearly all expenditure items turn out to be sacred cows. In any case, the final decision on this contentious issue will become evident not even from the anticrisis plan (that may well become underfunded, which already happened last year), but from the amendments to the Federal Law on the Federal Budget for 2016, which are planned to be adopted in accordance with the Q1 2016 financial results.

February saw a continuation of the government discussion of privatization issues (earlier, Minister of Finance Anton Siluanov had opined that additional budget revenue of about $\mathrm{Rb} 1$ trillion could be generated through privatization), joined by a new high-ranking participant - RF President Vladimir Putin. As a matter of fact, Mr. Putin put forth new demands (previously unheard of) - that state bank funds should not be used by investors (previously a widespread practice, which on the one hand seemed dubious, but on the other hand was profitable for the State because such credits were not interest-free); that state enterprise stakes must only be sold to buyers registered in Russia, and that such buyers must have a development strategy; and that 'strategic enterprises' should be excluded from privatization. In fact, these demands make large-scale privatization virtually impossible, because numerous Russian and all foreign businesses will be deprived of the right to participate in it. Moreover, only non-controlling blocks of shares in state-owned enterprises will be sold, which means that the new wave of privatization will follow in the footsteps of the previous one, which included the partial privatization of Sberbank, VTB and Rosneft.

In February, there were two noteworthy events clearly detrimental to the investment climate. The principal shareholder of Domodedovo Airport Dmitry Kamenshchik was apprehended and placed under house arrest on charges of negligence that allegedly made possible the suicide terror attack committed at the airport in 2011. Similar charges were also brought against a number of Domodedovo chief executives. So far, investigators have failed to explain in what respects the security situation at Domodedovo differs adversely from that at Russia's other major airports, because at that time none of them conducted the screening of all persons entering the airport. At Domodedovo, history repeats itself: in 2011 and 2012, the airport was severely criticized for 'security lapses' by Prime Minister Dmitry Medvedev, while in the mid-noughties the Federal Agency for State Property Management (Rosimushchestvo) filed a lawsuit designed to block the privatization of Domodedovo. On the whole, the Domodedovo affair indicates that none of Russia's big businesses can feel itself immune to the property problems typical of the Bashneft assets controversy. And such problems can always be created: where there's will there's a way. Property problems can likewise emerge - on a massive scale - for small businesses as well. Thus, scores of shopping centers, street kiosks and trade pavilions were destroyed overnight in Moscow. Some of those shops were twenty years old. None of them had ever caused any inconvenience. But now the Moscow city government has decided that the new version of the Civil Code gives it a carte blanche for demolishing any object without a court decision and compensation - simply because it does not correspond to the aesthetic views of city officials. Apparently, this arbitrary decision-making blatantly violates item 3 , Article 35 of the Constitution of the Russian Federation, which reads as follows: 'No one may be deprived 
of his property other than by decision of a court. The compulsory alienation of property for State needs may be done only on condition of advance and fair compensation.' The city government of St Petersburg eagerly followed in the footsteps of their Moscow colleagues, and it soon became clear that many governors are delighted with the aforesaid interpretation of the law. It is absolutely clear that the federal legislature and the federal judiciary must immediately intervene in this unprecedented situation, but so far the federal authorities have simply repeated the arguments put forth by the Moscow city government, including the absurd claims that Moscow is awash with 'illegally built objects'. The issue of responsibility on the part of officials (if and when any law violations are perpetrated in the course of demolition) or of the possibility of reaching a compromise have not even been mentioned, forget about addressed.

In February, Vladimir Dmitriev handed in his resignation as Chairman of State Corporation 'Bank for Development and Foreign Economic Affairs (Vnesheconombank)', an administrative position he had held for more than ten years. He was replaced by First Deputy Chairman of Sberbank Sergey Gor'kov. In 2015, Vnesheconombank' Board of Managers had announced that VEB urgently needed additional capitalization because of the $\mathrm{Rb} 250 \mathrm{bn}$ loss it had incurred in 2014. VEB had issued huge loans to investment banks that financed the construction of the Olympic Games facilities at Sochi. Also, VEB had heavily invested in a number of overseas projects - for example, it had acquired considerable assets in Ukraine. As a matter of fact, this corporation has become hostage to its political function: it could not ignore the Russian leadership's instructions to finance the commercially dubious Olympic Games objects, and as a result it has been accumulating losses over a long period of time. Also, the corporation was hit hard by being included into the EU's, USA's and Japan's lists of sanctioned individuals and entities, which considerably affected its ability to attract finance. The problems faced by VEB clearly indicate that major public projects must now be audited much more thoroughly than in the past (it should be noted that both the financing of the Sochi Olympic construction projects and the purchase, in Ukraine, of the steel producing group Industrial Union of Donbass and Prominvestbank were very expensive undertakings that cost VTB many billions of US dollars each). Despite their scope, such projects should not be shrouded in the thick veil of commercial secrecy and must be more transparent. Apparently, the first priority task of the corporation's new leadership will the quest for the financial resources necessary for VEB's additional capitalization. Minister of Finance Anton Siluanov has recently said that for now, only Rb 150 bn can be allocated for this purpose.

In the realm of foreign affairs, February saw some progress toward political solution in Syria. At midnight on 27 February, a ceasefire brokered by the USA and Russia and approved by the UN Security council came into effect. The essence of the ceasefire agreement is as follows: the Syrian Government and the Russian expeditionary force, on the one hand, and the rebel groups 'that have indicated their commitment to and acceptance of the terms for the cessation of hostilities' and are not designated by the UN Security Council as terrorist organizations, on the other, cease fire. For now, there are four rebel groups covered by the ceasefire. All of them are concentrated in the north-west and south-west of Syria - that is, in the areas that have seen the heaviest fighting in the last few months. On the eve of the ceasefire, there 
were misgivings that Turkey and Saudi Arabia might derail it by openly intervening in the Syrian conflict - both countries believe that the Assad regime perpetrates genocidal massacres of the Sunni population - but their regional and other allies managed to dissuade them from making such a rash and risky move. However, it is far from clear if any political solution can be possible under existing circumstances: the key issue is the future of Bashar al-Assad and his regime. In defiance of the roadmap for a sustainable political settlement in Syria worked out at the Vienna talks in November 2015 (which envisaged the following step-by-step process: a ceasefire; the formation of a transitional government; the conduct of fresh elections), Assad announced that parliamentary elections will be held in April. Apparently, the results of these elections will simply reflect the current situation in Syria, when the government does not control most of the country, but pretends to exercise sovereignty over the whole of its territory. Furthermore, it is worth remembering that since the beginning of the Syrian civil war in 2011, there have been a lot of ceasefires, but none of them held for long. Thus, it is most likely that Russia will have to shoulder the costs of her military involvement in the Syrian crisis over an indefinitely long period of time. 